\title{
北陸先端科学技術大学院大学 \\ マテリアルサイエンス研究科 山口研究室
}

山口政 之*

\section{1.はじめに}

北陸先端科学技術大学院大学 (英語名 Japan Advanced Institute of Science and Technology, 略称 JAIST) は, 科学と技術の分野で世界最高水準の研究と教育を行うこと を目的として 1990 年 10 月に設立された. 国立大学法人と しては, 学部を持たない初めての大学院大学である. 大学 設立当初は情報科学研究科, マテリアルサイエンス研究科 (2006 年 4 月 材料科学研究科から名称変更) が設置され たが, 1996 年に知識科学研究科も設置され, 現在の体制 (3つの研究科) に至っている.

マテリアルサイエンス研究科は，これからの先端科学技 術の進歩を担う, 広く深い知識を持った優れた人材の育成 を目的とし，1991 年に誕生した。原子，分子レベルから 物質を基礎的に研究する物質科学やナノマテリアル, 機能 性材料の創製, さらにバイオテクノロジーを包括する学際 的な教育と研究が大きな特徴となっている. 現在, 本研究 科には 34 の研究室があり, 50 名を超える教員, 300 名を 超える大学院生（うち, 約 100 名は博士後期課程）が最先 端の研究活動を行っている.

本学は, 日経産業新聞の調查（2004 年 2 月）で「独創 的な研究」の発案能力（競争的資金の獲得額）が全国で 5 位, 受託研究費の獲得額が 6 位, 学生あたりの教員数が 1 位, 工学部の研究力として 13 位にランク付けされるなど, 少数精鋭の研究組織であることが知られている.

さらに, 本学では, 産学連携や国際共同プロジェクトに も積極的であり, 2006 年 1 月現在, 17 力国 50 機関と学術 交流協定を結んでいる。また, 博士後期課程では, 全国の 国公私立の大学院修了者のみならず，社会人も積極的に受 け入れており, 産学連携の一助となっている.

\section{2. 研究室の研究内容}

\section{1 概要}

我々の研究室は, 2005 年 4 月に誕生したばかりの新し い研究室である. 同年 7 月に研究室の第 1 期生が配属とな り実質的な研究活動がスタートした。

\footnotetext{
* Yamaguchi, Masayuki 北陸先端科学技術大学院大学 マテリアルサイエンス研究科 山口研究室 能美市旭台 1-1（テ923-1292） 2006. 1.12 受理
}

当研究室では，レオロジーを材料開発の “手段” として 位置づけ, これによって新しい高性能・高機能ポリマー系 材料の設計を実施している．また，力学応答を決定づけて いる “構造”を分子レベル，さらには，ナノオーダーで捉 えることにより, 従来までのレオロジー研究よりも一歩進 んだ研究活動を目指している. また，当研究室は基礎学問 と企業での開発活動の隙間を埋める研究に重点を置いてお り，新しい材料の創製により社会に貢献することを大きな 目標としている.

今後の研究開発活動は，産官学を問わず，グローバルな 視点からの取り組みが必要になる。当研究室においても, アメリカ, ドイッ，カナダをはじめとする欧米の研究機関 と密接な関係を構築しており，グローバルな協力体制によ り研究活動を推進している.

以下に当研究室に扔いて実施している各研究テーマの内 容を簡単に記す。

\section{2 ポリオレフィンの高性能化}

ポリオレフィンを対象とした研究では，(1)ポリプロピ レン (PP) の透明性向上，(2) 低密度ポリエチレン (LDPE) を利用したレオロジーおよび加工特性の制御，（3）ポリオ レフィンの相溶性制御, を実施している.

(1) PP の透明性向上

PP を対象とした透明化剂であるソルビトール誘導体は, PP 中でナノオーダーのフィブリルを形成し透明性を発現 する. 当研究室では実際の成形品を考慮し, 流動場や冷却 条件がフィブリルの高次構造に及ぼす影響, さらには, フィ ブリルの高次構造と透明性との関係について研究を進めて いる. 得られた研究結果を基に, PPの更なる透明化に必 要となる材料設計指針を提案したいと考えている.

（2）LDPE を利用したレオロジーおよび加工特性の制御 代表的な分岐高分子である低密度ポリエチレン（LDPE） は強い溶融弾性を示し, それに基ついててさまざまな成形加 工が実施可能になっている。この強い溶融弾性の要因とし て長鎖分岐が関与したからみ合い相互作用が挙げられるが, 本相互作用は流動および熱履歴によって制御可能であるこ とが明らかになってきた。例えば，分子構造が全く同じ LDPEであっても，流動履歴や熱履歴を制御することによ り, 発泡成形に適した高溶融弾性タイプや高速押出が可能 な低溶融弾性タイプの設計が可能となる。また, 最近では, 特定の LDPE に特定の直鎖 PE を混合することで, LDPE 単独よりも強い溶融弾性を示すブレンドの設計も実現しつ 


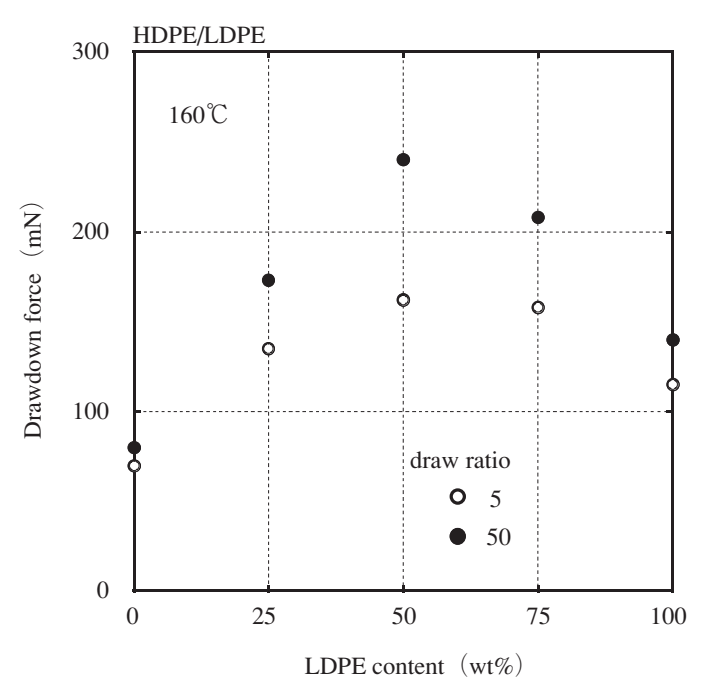

図 1 溶融延伸に必要な力の組成比依存性.

(LDPE/HDPE ブレンド) 直鎖高分子である HDPE と分岐高分子である LDPE の混合物は，その drawdown force がHDPE, LDPE のいずれよりも高 く, 強い溶融弾性を示す.

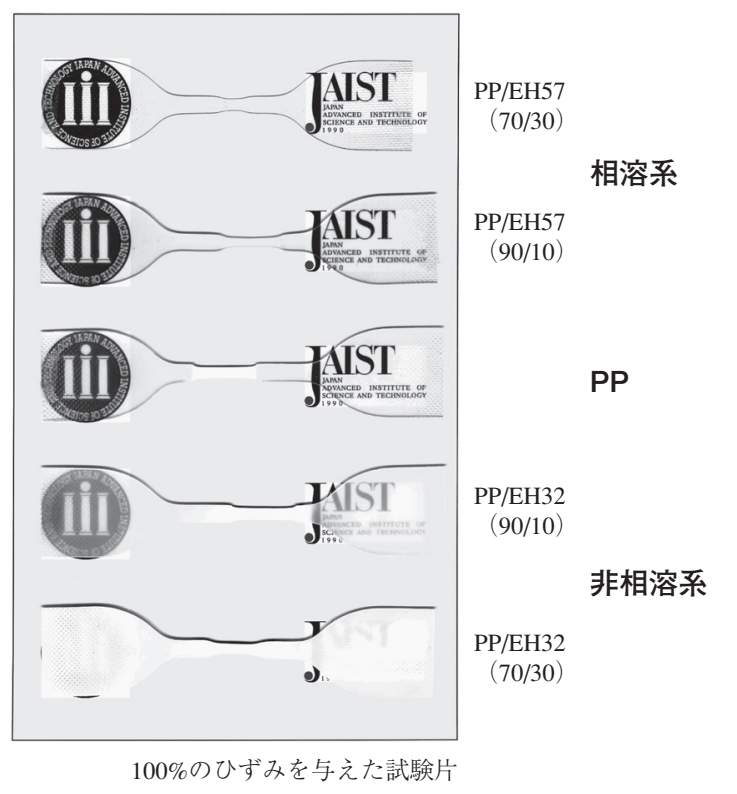

図 2 PP および PP とオレフィン系ゴムのブレンド. 上から順に，相溶系ブレンド (ゴム $10 \%$ )，相溶系 ブレンド (ゴム $30 \%), P P$, 非相溶系ブレンド（ゴ ム $10 \%)$ ，非相溶系ブレンド（ゴム $30 \%$ )

つある(図 1)。このように, LDPEを“上手に”扱うこ とで，ポリオレフィン系材料の高性能化を容易に行うこと ができる。

（3）ポリオレフィンの相溶性制御

我々はポリオレフィンの相溶性制御に関する基礎研究も 実施している。これまでにPP と分子状に相溶するオレ フィン系エラストマーを明らかにすると共に, 本特性を利 用した透明・軟質材料の開発も進めている（図 2).

相溶性に関する知見は，ポリオレフィン系材料のマテリ アルリサイクルに重要な知見となる. 今後も $\mathrm{PP}, \mathrm{PE}$
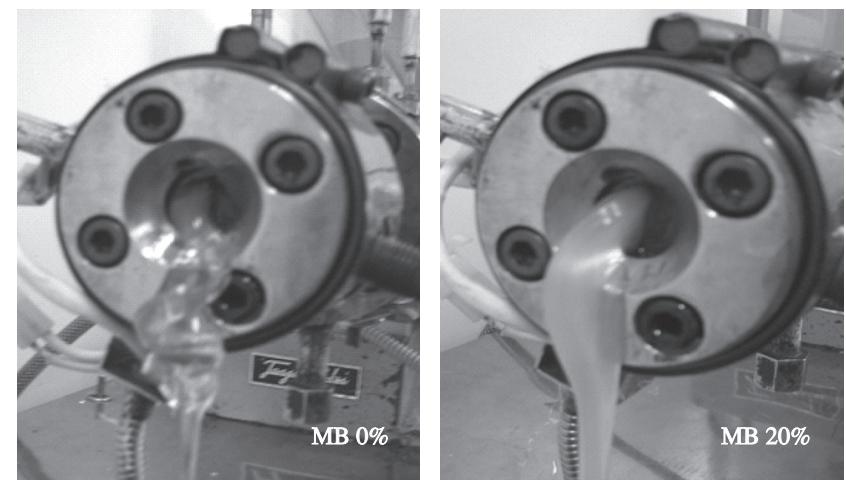

図 3 PET (左), 加工性改質剤のマスターバッチを混合 した試料（右）の押出加工性.

ダイ ガーベイタイプ. 加工性改質剂の混合でダイ の形状を保った押出物が得られると共に溶融垂れが 低減し, 押出加工性が大幅に改善する.

中心とした基礎研究を継続する予定である.

2.3 ポリエステル系樹脂の高性能・高機能化

ポリエステルを対象とした研究では，(1)リサイクルし たポリエチレンテレフタレート（PET）の加工改質，（2） バイオマス系プラスチックによる機能材料の設計，を実施 している。

(1) リサイクル PET の加工改質

PET のリサイクル率は年々増加しているが，一方でリ サイクル PET の再利用は社会的に大きな問題となってい る. その大きな原因は, 加水分解による低分子量化とそれ に伴う加工性の悪化である。我々は，反応性改質剤を用い た反応押出によるレオロジー制御を実施しており, リサイ クル PET の有効利用を促進できるよう研究を進めている. 図 3 に異形押出評価用として用いられるガーベイタイプの ダイから押出した試料の状態を示す. 反応性改質剤のマス ターバッチを混合することで，ダイの形状を維持した押出 加工が可能になる.

また, 今後は, PET 系共重合体や PBT（ポリブチレン テレフタレート）にも着目し，エステル系高分子材料の高 性能化について検討を実施する予定である。

(2) バイオマス系プラスチックによる機能材料の設計 石油化学系プラスチックに代わる次世代のプラスチック 材料として, バイオマス由来のエステル系高分子材料が注 目されている. 当研究室では, 単に汎用プラスチックの代 替としてではなく, バイオマス系プラスチックの特長を活 かした新しい機能性材料の設計を目指している。具体的に は，透明性ポリマーアロイによる光学材料の設計，環境修 復能力を示す機能性発泡体の設計が挙げられる. 光学材料 としては, ナノオーダーで複合材料の構造を制御すること により透明性を維持し, さらに, 高勒性, 低複屈折などの 特性を付与すべく研究を進めている. また, 環境修復材料 としてはポリヒドロキシ酪酸 (PHB) の優れた生分解性 を利用した材料開発を進めている. PHBに対する発泡成 形性の付与は, 当研究室にて明らかにした臨界点近傍ゲル によるレオロジー改質法の利用を試みている（図 4).

\section{4 機能性材料の設計}

素材を限定しない新しい機能性高分子材料の設計も実施 している。具体例としては, 新しいコンセプトを利用した 

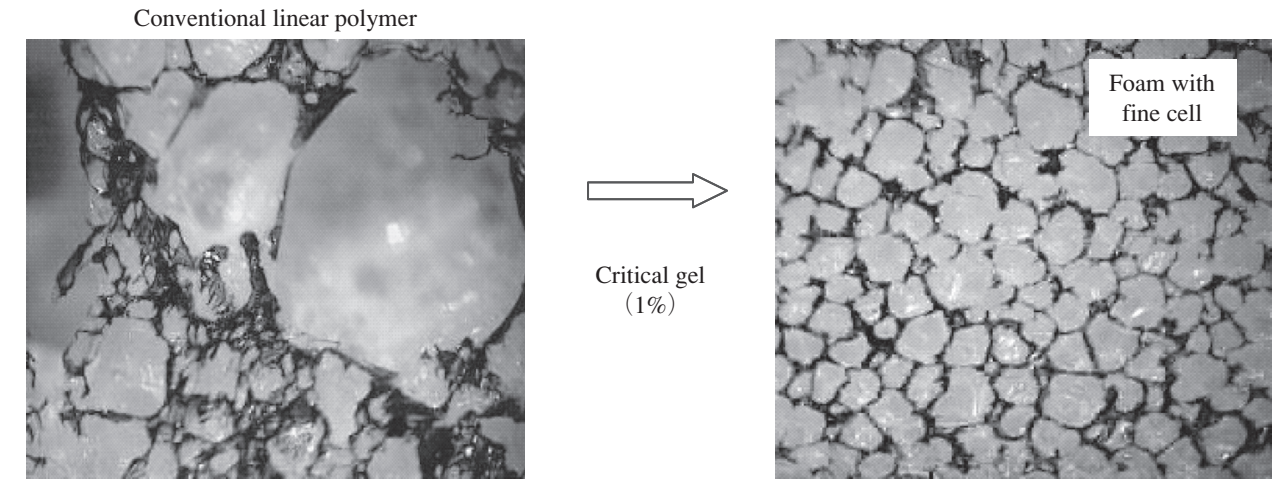

図 4 直鎖高分子の発泡成形性 (左), 臨界点近傍ゲルを混合した後の発泡 成形性 (右) (化学発泡剂による発泡). 直鎖状高分子は一般的に発泡 成形性に劣るものの, 臨界点近傍のゲルを少量添加することで溶融弾 性が著しく向上し, 発泡成形が可能になる.
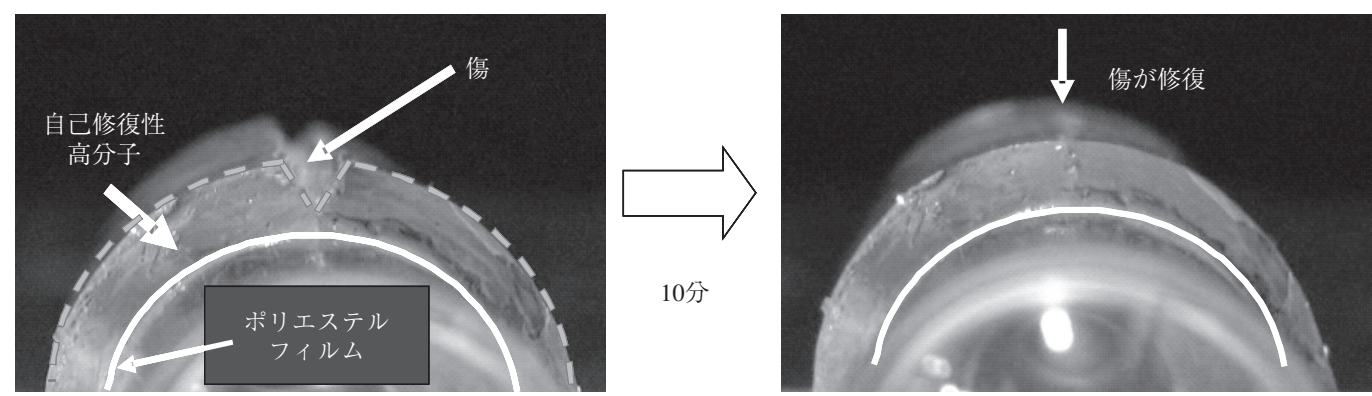

図 5 ポリエステルフィルムに貼り合わせた自己修復性高分子.

剃刀で傷をつけた後, 10 分放置すると傷は修復する. なお, 写真撮影時の み試験片を筒に巻きつけ, 傷を確認しやすいようにシートをカールさせて いる.

自己修復性高分子材料（図 5)，吸音性高分子材料が挙げ られる。自己修復性高分子は, 各種表皮材料, 光学材料, 生体材料などへの応用が期待され，吸音材は建材分野を中 心として強いニーズがある。これらの機能材料の分子およ び材料設計を進め，暮らしを豊かにする高分子材料の開発 に繋げることを目標としている.

\section{3.おわりに}

これまで述べたように，当研究室では企業の研究開発を
強く意識した研究テーマを設定している. 産学連携により, お互いの研究開発活動が少しでも前進したら幸甚である. 大学のホームページ

http : //www.jaist.ac.jp/index-j2.shtml マテリアルサイエンス研究科のホームページ

http : //www.jaist.ac.jp/ms/index.html 山口研究室のホームページ

http : //www.jaist.ac.jp/ms/labs/yamaguchi/ 